\title{
Short-Term Soil Nitrous Oxide Emissions as Affected by Enhanced Efficiency Nitrogen Fertilizers and Temporarily Waterlogged Conditions
}

\author{
Brendan A. Zurweller ${ }^{1}$, Peter P. Motavalli ${ }^{2}$, Kelly A. Nelson ${ }^{3} \&$ Christopher J. Dudenhoeffer ${ }^{3}$ \\ ${ }^{1}$ Agronomy Department, University of Florida, Gainesville, FL, USA \\ ${ }^{2}$ Department of Soil, Environmental and Atmospheric Sciences, University of Missouri, Columbia, MO, USA \\ ${ }^{3}$ Division of Plant Sciences, University of Missouri, Novelty, MO, USA \\ Correspondence: Brendan A. Zurweller, Agronomy Department, University of Florida, 3105 McCarty Hall B, \\ P.O. Box 110500, Gainesville, FL 32611, USA. Tel: 1-352-273-3408. E-mail: bzcn7@ufl.edu
}

Received: August 24, 2015 Accepted: October 26, 2015 Online Published: November 15, 2015

doi:10.5539/jas.v7n12p1 URL: http://dx.doi.org/10.5539/jas.v7n12p1

\begin{abstract}
Poorly-drained claypan soils in the Midwestern United States experience periods of short-term soil saturation shortly after pre-plant $\mathrm{N}$ fertilization, which may result in relatively large amounts of soil surface $\mathrm{N}_{2} \mathrm{O}$ emissions. Slowing the release or conversion of $\mathrm{N}$ fertilizer to soil $\mathrm{NO}_{3}$ early in the growing season through the use of enhanced efficiency fertilizers (EEF) could be an effective strategy for reducing soil $\mathrm{N}_{2} \mathrm{O}$ emissions and gaseous $\mathrm{N}$ loss during a period of relatively low plant $\mathrm{N}$ demand. The objective of this study was to determine the effects of short-term soil waterlogging and pre-plant applications of conventional and EEF on soil inorganic $\mathrm{N}_{\text {and }} \mathrm{N}_{2} \mathrm{O}$ emissions during and up to four days following a waterlogging event during the dry down period. A two-year field study planted to corn (Zea mays L.) was initiated in 2012 on a poorly-drained claypan soil in Northeast Missouri. Waterlogging treatments were initiated at the V6 corn stage of phenological development. Main plots consisted of no waterlogging or water ponded 7 to $13 \mathrm{~cm}$ above the soil surface for three days, and sub-plot $\mathrm{N}$ fertilizer treatments [non-treated control (CO), or preplant broadcast applications of $168 \mathrm{~kg} \mathrm{~N} \mathrm{ha}^{-1}$ of urea (NCU), urea plus nitrapyrin nitrification inhibitor (NCU+NI), and polymer coated urea (PCU)]. In 2012, greater cumulative soil $\mathrm{N}_{2} \mathrm{O}-\mathrm{N}$ emissions of $2.8 \mathrm{~kg} \mathrm{~N}_{2} \mathrm{O}-\mathrm{N} \mathrm{ha}^{-1}$ were observed with PCU in comparison to NCU over the entire seven day sampling period. A significant portion of cumulative soil $\mathrm{N}_{2} \mathrm{O}$ emissions were associated with the four day soil drying phase in 2012, where PCU and NCU+NI had greater emissions (1.9 and $1.2 \mathrm{~kg} \mathrm{~N} \mathrm{~N}_{2} \mathrm{O}-\mathrm{N}$ $\mathrm{ha}^{-1}$ ) compared to NCU. The proportion of $\mathrm{N}$ fertilizer lost as $\mathrm{N}_{2} \mathrm{O}-\mathrm{N}$ averaged over all pre-plant $\mathrm{N}$ treatments during the 2012 and 2013 sampling periods in the non-waterlogged soils were $0.04 \%$ and $0.03 \%$, and $1.1 \%$ and $2.6 \%$ in the waterlogged soils, respectively. These results suggest that a large proportion of the cumulative soil surface $\mathrm{N}_{2} \mathrm{O}$ emissions typically observed in these poorly-drained soils over a growing season may occur during and shortly after soil waterlogging events.
\end{abstract}

Keywords: soil waterlogging, nitrous oxide, corn, polymer-coated urea, nitrification inhibitor, claypan soil

\section{Introduction}

Nitrous oxide $\left(\mathrm{N}_{2} \mathrm{O}\right)$ is a persistent greenhouse gas that has been estimated to have a long theoretical lifetime in the atmosphere (Prinn et al., 1990). With a global warming potential 298 times greater than $\mathrm{CO}_{2}$, it is responsible for $11 \%$ of the net anthropogenic radiative force, and for the destruction of stratospheric ozone (Millar et al., 2010, Soloman et al., 2007; Wuebbles, 2009). A significant source of $\mathrm{N}_{2} \mathrm{O}$ emissions are from agricultural soils and these emissions will most likely increase as a result of a projected three-fold increase in $\mathrm{N}$ fertilizer use by the year 2050 (Tilman et al., 2002).

The United States (U.S.) is currently the third largest consumer of $\mathrm{N}$ fertilizer and U.S. agricultural cropping systems account for approximately $71 \%$ of U.S. $\mathrm{N}_{2} \mathrm{O}$ emissions (FAO, 2009; USEPA, 2009). An agricultural area of the U.S. that is susceptible to $\mathrm{N}_{2} \mathrm{O}$ loss is the Central Claypan Region that comprises 4 million hectares in parts of Missouri, Illinois, and Kansas (Anderson et al., 1990; Nash et al., 2012). Claypan soils are characterized by poor drainage which often contributes to soil saturation or waterlogging following a precipitation event. These waterlogged soil conditions can create favorable conditions for soil denitrification including soil $\mathrm{N}_{2} \mathrm{O}$ 
efflux. In general, the optimal water-filled pore space (WFPS) for denitrification and $\mathrm{N}_{2} \mathrm{O}$ emissions ranges from 60 to $80 \%$, whereas WFPS over $80 \%$ starts to favor the generation of dinitrogen $\left(\mathrm{N}_{2}\right)$ gas (Zhu \& Sikora, 1995). In a meta-analysis from $846 \mathrm{~N}_{2} \mathrm{O}$ emission measurements in agricultural fields, Bouwman et al. (2002) found that soil $\mathrm{N}_{2} \mathrm{O}$ emissions were $35 \%$ greater in poorly drained soils than in well drained soils. Other factors that affect soil $\mathrm{N}_{2} \mathrm{O}$ emissions include soil available carbon, soil $\mathrm{NO}_{3}{ }^{-}$concentration, soil temperature, and soil $\mathrm{pH}$ (Bakken \& Dörsch, 2007; Chintala et al., 2014).

Enhanced efficiency $\mathrm{N}$ fertilizer products are intended to improve $\mathrm{N}$ use efficiency and reduce $\mathrm{N}$ losses to the environment compared to conventional $\mathrm{N}$ fertilizer sources (AAPFCO, 2013). Several studies have examined the effectiveness of both polymer-coated urea and non-coated urea treated with nitrapyrin nitrification inhibitor EEF products in reducing soil $\mathrm{N}_{2} \mathrm{O}$ emissions under corn production. Halvorson et al. (2013) reported a $42 \%$ reduction in soil $\mathrm{N}_{2} \mathrm{O}$ emissions with $\mathrm{PCU}$ in comparison with urea under irrigated corn production on a clay loam soil when no-till and strip-till were practiced, but no significant reduction in emissions with conventional tillage. Bronson et al. (1992) reported a three-fold reduction in soil $\mathrm{N}_{2} \mathrm{O}$ emissions with $\mathrm{NCU}+\mathrm{NI}$ in comparison to urea when measured in the first 40 days after $\mathrm{N}$ fertilization. A meta-analysis by Akiyama et al. (2010) reported an overall effectiveness of EEF products on soil $\mathrm{N}_{2} \mathrm{O}$ emissions across varying environmental factors and field management. They concluded that nitrification inhibitors and PCU reduced $\mathrm{N}_{2} \mathrm{O}$ emissions on average by 38 and $35 \%$ compared to non-treated and conventional fertilizers, respectively.

Many studies have examined the effectiveness of PCU and NCU+NI in reducing $\mathrm{N}_{2} \mathrm{O}$ emissions in corn, but little research has been conducted on the use of these products under temporarily waterlogged conditions in poorly drained upland soils planted with corn. Poorly drained claypan soils in Northeast Missouri are vulnerable to extended soil saturation periods during the spring months as a result of high intensity rainfall events that often occur during this period. Villarini et al. (2013) reported increasing trends of heavy rainfall over the north central United States by analyzing daily rainfall records from 447 rain gauge stations. Future predictions for the mid- $21^{\text {st }}$ century are generally wetter conditions during the months of April to May for the Midwest U.S. region which may influence $\mathrm{N}$ fertilizer management in the region (Patricola \& Cook, 2012). Large pulses of soil $\mathrm{N}_{2} \mathrm{O}$ emissions are likely during the spring time because $\mathrm{N}$ fertilizer is often applied at this time before planting, potentially causing increased soil $\mathrm{N}_{2} \mathrm{O}$ emissions due to relatively high soil water content and elevated soil $\mathrm{NO}_{3}{ }^{-}$ concentrations (Bakken \& Dörsch, 2007).

Significant soil $\mathrm{N}_{2} \mathrm{O}$ emissions are also possible under anaerobic conditions as a result of nitrifier denitrification, which occurs under waterlogged conditions or as a soil dries from a saturated state. Zhu et al. (2013) observed increased $\mathrm{N}_{2} \mathrm{O}$ production through the $\mathrm{NH}_{3}$ oxidative pathway when $\mathrm{O}_{2}$ concentrations decreased from 21 to $0.5 \%$ oxygen and $\mathrm{N}_{2} \mathrm{O}$ production was greater through the $\mathrm{NH}_{3}$ oxidative pathway in comparison to the heterotrophic denitrification pathway at $3 \% \mathrm{O}_{2}$. Field studies in rice production have reported $74 \%$ of cumulative soil $\mathrm{N}_{2} \mathrm{O}$ emissions to occur during the soil drying phases with controlled irrigation in comparison to $20 \%$ during traditional irrigation drainage at mid-season and maturity (Peng et al., 2011). In a four-year field study by Ji et al. (2012), controlled released fertilizers reduced $\mathrm{N}_{2} \mathrm{O}$ emissions by $13 \%$ compared to urea.

The objective of this study was to determine the effects of soil waterlogging and applications of conventional and EEF products on soil $\mathrm{N}_{2} \mathrm{O}$ emissions under a corn production system in a poorly-drained claypan soil. We hypothesized that the incremental release and other properties of the EEF products may lead to reduced soil $\mathrm{N}_{2} \mathrm{O}-\mathrm{N}$ emissions when compared with the $\mathrm{N}_{2} \mathrm{O}-\mathrm{N}$ emissions resulting from the use of conventional urea during a period of soil waterlogging. Results from this research may provide management strategies to reduce $\mathrm{N}_{2} \mathrm{O}-\mathrm{N}$ emissions in poorly drained soils which are susceptible to significant soil $\mathrm{N}_{2} \mathrm{O}-\mathrm{N}$ emissions and $\mathrm{N}$ loss during relatively short time periods over the growing season.

\section{Method}

\subsection{Site Characterization and Experimental Design}

This two-year study was initiated in 2012 on a poorly-drained claypan soil in Northeast Missouri at the University of Missouri's Greenley Memorial Research Center $\left(40^{\circ} 1^{\prime} 17^{\prime \prime} \mathrm{N}, 92^{\circ} 11^{\prime} 24.9^{\prime \prime} \mathrm{W}\right)$. A different site was used for the 2013 cropping year to avoid residual effects of the experimental treatments. The soil for both sites is classified as a Putnam silt loam (fine, smectitic, mesic, Vertic Albaqualfs) (Watson, 1979). Initial soil samples were collected each year prior to the application of the $\mathrm{N}$ fertilizer treatments to characterize the soil at depth increments of $0-10,10-20$, and $20-30 \mathrm{~cm}$ using a stainless steel push probe. Composite samples of 10 soil cores were collected in each of the untreated replicates. All soil samples were air-dried and ground to pass through a sieve with $2 \mathrm{~mm}$ openings. The initial soil samples were analyzed by the University of Missouri Soil and Plant Testing Laboratory using standard soil testing procedures (Nathan et al., 2006). Soil bulk density was determined 
using the core method at depth increments of 0-10, 10-20, and 20-30 cm and one core per each depth were taken per replicate (Blake et al., 1986).

The experiment was a randomized complete block design with a split-plot arrangement with no waterlogging or 3-day waterlogging as the main plot treatments and pre-plant $\mathrm{N}$ fertilizer treatments as the subplot treatments with three replications. Each plot consisted of six rows (30.5 meters in length with $76.2 \mathrm{~cm}$ between rows) planted to 'DEKALB 62-97VT3' (Monsanto, St. Louis, Missouri) at 79,040 seeds ha ${ }^{-1}$. Two different field locations at the Greenley Research Center were used for the 2012 and 2013 research trials and these locations had previously been in a corn-soybean rotation.

Waterlogging treatments ( 0 and 3-d of waterlogging duration) consisted of water ponded 7 to $13 \mathrm{~cm}$ above the soil surface and were initiated at the V6 growth stage (marked when $50 \%$ or more of plants in the field are at or beyond 6 fully expanded leaves with visible leaf collars) using temporary soil levees to surround each main plot formed by a 824 levee plow (W \& A Manufacturing Co., Pine Bluff, Arkansas). Vegetative growth stage V6 was identified using the leaf collar method (Abendroth et al., 2011). Levees were removed to allow ponded water to escape after the three day waterlogging duration was completed.

Nitrogen fertilizer treatments included a non-treated control, conventional urea, conventional urea plus nitrapyrin (2-chloro-6-(trichloro-methyl) pyridine) nitrification inhibitor at $2 \mathrm{~L} \mathrm{ha}^{-1}$ (N-Serve ${ }^{\circledR}$, Dow AgroSciences, Indianapolis, Indiana), and polymer-coated urea $\left(\mathrm{ESN}^{\circledR}\right.$, Agrium, Inc., Calgary, Alberta) applied at $168 \mathrm{~kg} \mathrm{~N} \mathrm{ha}^{-1}$ prior to planting. All fertilizer $\mathrm{N}$ treatments were broadcast using a hand spreader and incorporated immediately after application to a depth of $15 \mathrm{~cm}$ using a Tilloll (Landoll Corp., Marysville, KS). In 2012, N fertilizer treatments were applied on 3 April and the waterlogging treatment was on 1 June. In 2013, N fertilizer treatments were applied on 14 May and the waterlogging treatment occurred on 18 June.

\subsection{Field Measurements}

Measurements for soil $\mathrm{N}_{2} \mathrm{O}$ efflux were in accordance with the USDA-ARS GRACEnet protocol for trace gas sampling and analysis (Parkin \& Venterea, 2010). Two PVC static ring chambers $23 \mathrm{~cm}$ long by $20 \mathrm{~cm}$ in diameter were placed $7.5 \mathrm{~cm}$ into the soil surface in each pre-plant $\mathrm{N}$ treatment of the non-waterlogged and 3-d waterlogged treatments. One chamber was placed in the corn row and one chamber was placed between the corn rows to obtain a representative sample. Each static chamber was vented using a $10 \mathrm{~cm}$ long by $0.64 \mathrm{~cm}$ diameter copper tubing installed into a rubber cap equipped with a sampling port. Chamber headspace evacuated from the static chamber was conducted using a $60 \mathrm{~mL}$ Luer-Lok polypropylene syringe with a 16 gauge by $3.8 \mathrm{~cm}$ long needle (Becton, Dickingson and Company, New Jersey, United States). Immediately after headspace was drawn into the syringe, $25 \mathrm{~mL}$ of the sampled gas was injected in an evacuated $12 \mathrm{ml}$ glass vial to create an over pressurized vial (Labco Exetainer, Labco, United Kingdom). Sampling of static chamber headspace for soil $\mathrm{N}_{2} \mathrm{O}$ estimations occurred at time intervals of 0,30 , and 60 minutes. Analysis of gas samples for $\mathrm{N}_{2} \mathrm{O}$ concentration was determined on a gas chromatograph (GC) with a methanizer, flame ionization detector, and an electron capture detector for measuring $\mathrm{N}_{2} \mathrm{O}$ concentrations (Shimadzu, Kyoto, Japan). The $\mathrm{N}_{2} \mathrm{O}$ standards were prepared by Matheson Tri-Gas, Inc. (Montgomeryville, PA) with a purity analysis greater than $99 \%$ at concentrations of 1 , $5,12,25$, and 500 parts per million (ppm). Trends in $\mathrm{N}_{2} \mathrm{O}$ concentrations were assessed for curvi-linearity using the empirical data curvi-linearity index equation with a GC precision of $2 \%$ (Parkin \& Venterea, 2010). For curvi-linear data the Hutchinson and Mosier algorithm was used in determining gas efflux and linear regression was used to determine soil $\mathrm{N}_{2} \mathrm{O}$ efflux for non-curvilinear data (Parkin \& Venterea, 2010).

Gas sampling was performed on the day prior to initiation of the waterlogging treatments, two times daily during the three day waterlogging period, and two times following the draining of the waterlogging treatment. In 2012, gas sampling was conducted two and four days after the three day waterlogging treatment had been drained, and in 2013 the gas sampling was done two and three days following the three day waterlogging duration. The cumulative emissions over and after the waterlogging duration was calculated using linear regression to determine the slope of the line between each consecutive gas efflux measurements. This slope was then multiplied by the time interval between sampling points and summed together to estimate cumulative $\mathrm{N}_{2} \mathrm{O}-\mathrm{N}$ emission between measurement periods. Soil $\mathrm{N}_{2} \mathrm{O}-\mathrm{N}$ emissions during the soil waterlogging and drying periods were determined by interpolating from the point in time when the impounded water was released. Time before this point was totaled into soil $\mathrm{N}_{2} \mathrm{O}-\mathrm{N}$ emissions during waterlogging and time beyond this point was totaled into soil $\mathrm{N}_{2} \mathrm{O}-\mathrm{N}$ emissions after the three days of waterlogging had ended.

Environmental conditions were characterized during gas sampling times. Measurements of soil surface $\mathrm{E}_{\mathrm{h}}$ were recorded in the plots where waterlogging occurred with a portable millivolt meter using an $\mathrm{Ag} / \mathrm{AgCl}$ electrode saturated in $4 \mathrm{M} \mathrm{KCl}$ solution (Oakton $310 \mathrm{pH}$ meter, Vernon Hills, IL; Cole Palmer ORP/pH 3' submersible, 
Vernon Hills, IL). The electrode was inserted into the waterlogged soil to a depth of approximately $2.5 \mathrm{~cm}$. Soil $\mathrm{E}_{\mathrm{h}}$ was converted to the standard $\mathrm{H}_{2}$ reference electrode values (Vepraskas et al., 2002). At each gas sampling chamber, soil temperatures and a soil sample at a $10 \mathrm{~cm}$ depth were collected (Oakton Temp 10 Thermocouple, Vernon Hills, IL). These soil samples were analyzed for soil gravimetric water content, and soil $\mathrm{NH}_{4}{ }^{+}-\mathrm{N}$ and $\mathrm{NO}_{3}{ }^{-}-\mathrm{N}$ concentration using a $2 \mathrm{M} \mathrm{KCl}$ extraction and analysis with a Lachat 8400 series II automated ion analyzer (Hach Corp., Loveland, CO) (QuikChem Method 12-107-04-1-B). Daily precipitation information was obtained from an automated weather station located within $500 \mathrm{~m}$ of the experiment.

\subsection{Statistical Analysis}

Statistical analysis for initial soil characteristics, soil redox potential in waterlogged plots, and soil temperature and water content are assessed by plus or minus one standard deviation of subsamples across three replications. Analysis of variance (ANOVA) was performed for soil $\mathrm{NO}_{3}{ }^{-} \mathrm{N}, \mathrm{NH}_{4}{ }^{+} \mathrm{N}$, and $\mathrm{N}_{2} \mathrm{O}-\mathrm{N}$ emissions using SAS v. 9.3 (SAS Institute, 2013) PROC MIXED model. Waterlogging and $\mathrm{N}$ fertilizer were analyzed as random effects. Multiple comparison significance for soil $\mathrm{NH}_{4}{ }^{+}-\mathrm{N}, \mathrm{NO}_{3}^{-}-\mathrm{N}$ and $\mathrm{N}_{2} \mathrm{O}-\mathrm{N}$ emissions was determined using Fisher's Least Significant Difference (LSD) at the $\mathrm{P} \leq 0.10$ probability level. Due to a significant statistical effect of site year, data for each year were separated and analyzed independently.

\section{Results and Discussion}

\subsection{Initial Soil Characteristics}

Results of the initial soil analysis indicated an adequate amount of Bray I-P and exchangeable potassium, calcium, and magnesium based on University of Missouri fertilizer recommendations for corn (Buchholz, 2004) (Table 1). The soils at the experimental site in 2012 had a higher soil $\mathrm{pH}_{\mathrm{s}}$ of 0.7 in the $0-10 \mathrm{~cm}$ depth when compared to that in 2013. The concentration of $\mathrm{NH}_{4}{ }^{+}-\mathrm{N}_{\text {plus }} \mathrm{NO}_{3}{ }^{-} \mathrm{-}$ prior to pre-plant $\mathrm{N}$ treatments was 40.5 and $50.2 \mathrm{mg} \mathrm{N} \mathrm{kg}^{-1}$ soil when summed to a depth of $30 \mathrm{~cm}$ for 2012 and 2013, respectively. In general, $2012 \mathrm{had}$ a decrease in soil $\mathrm{NO}_{3}^{-}-\mathrm{N}$ with increasing sampling depth, whereas $\mathrm{NO}_{3}^{-}-\mathrm{N}$ increased with sampling depth in 2013. This result suggested some possible residual $\mathrm{N}$ carried over to the 2013 season because of the relatively dry 2012 season.

Table 1. Selected initial soil characteristics for 2012 and 2013. Data were averaged over three replications by soil depth

\begin{tabular}{|c|c|c|c|c|c|c|c|c|c|c|c|c|}
\hline Year $^{\dagger}$ & Depth & $\mathrm{OM}$ & $\mathrm{pH}_{\mathrm{s}}$ & NA & CEC & $\begin{array}{l}\text { Bray } \\
1 \mathrm{P}\end{array}$ & Exch. Ca & $\begin{array}{l}\text { Exch. } \\
\text { Mg }\end{array}$ & Exch. K & B.D. & $\mathrm{NO}_{3}^{-}-\mathrm{N}$ & $\mathrm{NH}_{4}{ }^{+}-\mathrm{N}$ \\
\hline & $\mathrm{cm}$ & $\mathrm{g} \mathrm{kg}^{-1}$ & & ------cmo & $\mathrm{kg}^{-1}$ & (-. & ---kg & $1 \quad \ldots$ & ב---- & $\mathrm{g} \mathrm{cm}^{-3}$ & ----mg N & goil soi $^{-1}$--- \\
\hline \multirow[t]{3}{*}{2012} & $0-10$ & $27 \pm 3.0$ & $6.1 \pm 0.4$ & $1.8 \pm 1.4$ & $15.2 \pm 1.3$ & $65.0 \pm 9$ & $5151 \pm 436$ & $395 \pm 37$ & $407 \pm 61$ & $1.43 \pm 0.05$ & $6.7 \pm 3.0$ & $11.1 \pm 1.9$ \\
\hline & $10-20$ & $20 \pm 3.0$ & $6.3 \pm 0.4$ & $1.5 \pm 0.9$ & $15.1 \pm 0.1$ & $23.2 \pm 4$ & $5367 \pm 362$ & $380 \pm 10$ & $200 \pm 14$ & $1.48 \pm 0.14$ & $4.1 \pm 1.1$ & $7.6 \pm 0.7$ \\
\hline & $20-30$ & $17 \pm 2.0$ & $5.5 \pm 0.5$ & $4.0 \pm 1.3$ & $17.8 \pm 2.3$ & $8.60 \pm 2$ & $5114 \pm 246$ & $570 \pm 86$ & $211 \pm 20$ & $1.46 \pm 0.01$ & $3.0 \pm 0.4$ & $8.0 \pm 2.1$ \\
\hline \multirow[t]{3}{*}{2013} & $0-10$ & $28 \pm 1.0$ & $5.4 \pm 0.1$ & $3.7 \pm 0.6$ & $13.9 \pm 0.2$ & $83.2 \pm 8$ & $3698 \pm 148$ & $384 \pm 15$ & $438 \pm 32$ & $1.11 \pm 0.02$ & $11.4 \pm 3.0$ & $3.7 \pm 0.4$ \\
\hline & $10-20$ & $20 \pm 2.0$ & $5.9 \pm 0.3$ & $2.5 \pm 0.9$ & $14.0 \pm 0.6$ & $26.0 \pm 5$ & $4351 \pm 204$ & $426 \pm 12$ & $221 \pm 40$ & $1.30 \pm 0.07$ & $11.9 \pm 2.4$ & $3.4 \pm 0.2$ \\
\hline & $20-30$ & $18 \pm 1.0$ & $5.2 \pm 0.5$ & $4.7 \pm 2.1$ & $16.5 \pm 2.8$ & $14.6 \pm 3$ & $4248 \pm 179$ & $549 \pm 79$ & $235 \pm 179$ & $1.26 \pm 0.05$ & $16.0 \pm 3.8$ & $3.8 \pm 0.8$ \\
\hline
\end{tabular}

Note. $†$ Abbreviations: $\mathrm{pH}_{\mathrm{s}}$ in $0.01 \mathrm{M} \mathrm{CaCl}_{2}$; NA, Neutralizable Acidity; OM, Organic Matter; P, Bray-1 Phosphorus; Exch. Ca, Exchangeable Calcium; Exch Mg, Exchangeable Magnesium; Exch. K, Exchangeable Potassium; CEC, Cation Exchange Capacity; B.D, Bulk Density; $\mathrm{NO}_{3}{ }^{-} \mathrm{N}$, Nitrate Nitrogen; $\mathrm{NH}_{4}{ }^{+}{ }^{-} \mathrm{N}$, Ammonium Nitrogen; \pm , plus or minus one standard deviation.

\subsection{Climatic Conditions}

Total cumulative precipitation from seed planting to grain harvest was 273 and $372 \mathrm{~mm}$ for 2012 and 2013, respectively (University of Missouri Extension, 2014) (Figure 1). There was variation throughout the 2013 growing season with intense spring rains resulting in the 15th wettest April-June time period during the past 120 years (NOAA, 2013). Drier and warmer spring temperatures promoted an earlier planting date in 2012 in comparison with that of 2013 (NOAA, 2012). This earlier planting date resulted in an earlier initiation of the waterlogging treatment at growth stage V6 in 2012 than in 2013. Another notable difference between the two years was that approximately $18 \mathrm{~mm}$ of precipitation occurred the day prior to implementing the waterlogging 
treatments in 2012, and in 2013 a precipitation event of $33.5 \mathrm{~mm}$ occurred three days prior to implementation of the waterlogging treatment. These conditions may have affected gaseous $\mathrm{N}$ loss prior to the initiation of sampling in this experiment.

\subsection{Environmental Conditions during Waterlogging}

Greater air temperatures in 2013 resulted in warmer average soil temperatures of $4.2{ }^{\circ} \mathrm{C}$ at a depth of $10 \mathrm{~cm}$ during $\mathrm{N}_{2} \mathrm{O}$ sampling times compared to 2012 (Figures 2A and 2B). In both research seasons, no significant temperature differences were observed between non-waterlogged and waterlogged soils. The average gravimetric soil water content during gas sampling in 2012 was 0.22 and $0.40 \mathrm{~g}$ water $\mathrm{g}^{-1}$ soil $^{-1}$ for the non-waterlogged and waterlogged treatments, respectively (Figures 2C and 2D). In 2013, the non-waterlogged treatment had an average gravimetric water content of $0.31 \mathrm{~g}^{-1}$ water g $\mathrm{g}^{-1}$ soil $^{-1}$ and the waterlogged treatment had an average gravimetric water content of $0.36 \mathrm{~g}_{\text {water }} \mathrm{g}^{-1}$ soil $^{-1}$. Soil surface $\mathrm{E}_{\mathrm{h}}$ after three days of waterlogging averaged 448 and $368 \mathrm{mV}$ in 2012 and 2013, respectively (Table 2). This soil redox potential is considered the threshold between a weakly reduced suboxic to oxic soil environment (Berner et al., 1981; Reddy et al., 2000; Sposito et al., 1989; Zhi-Guang, 1985). Other researchers in a soil incubation study, observed increased soil $\mathrm{N}_{2} \mathrm{O}$ emissions under moderate reducing conditions at an $\mathrm{E}_{\mathrm{h}}$ in the range of 420 to $575 \mathrm{mV}$ in soils under continuous corn that had a history of either urea-ammonium nitrate solution (UAN) or manure application (Hernandez-Ramirez et al., 2009).

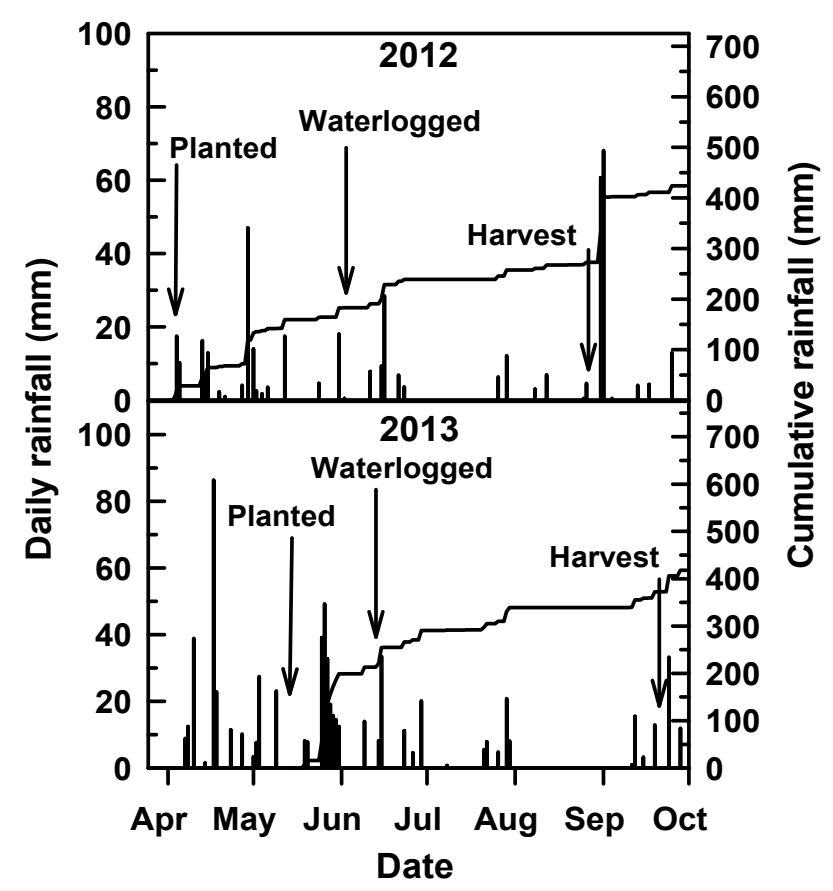

Figure 1. Daily and cumulative (line) precipitation during the corn growing seasons for 2012 and 2013.

Cumulative rainfall was determined starting at planting for both years 


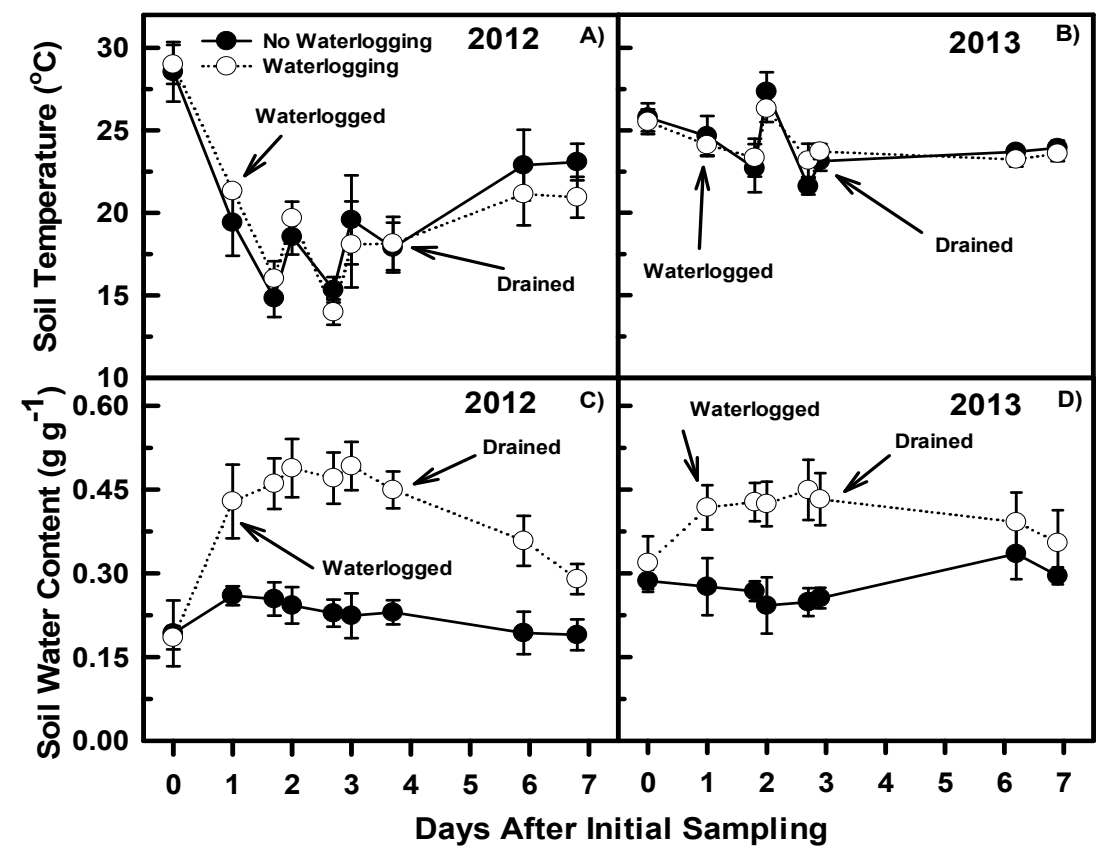

Figure 2. Average soil temperatures (A \& B) and gravimetric water content $(C \& D)$ at a depth of $10 \mathrm{~cm}$ recorded at the time of gas sampling in the non-waterlogged and waterlogged treatments for 2012 and 2013. The first sampling period occurred the day before waterlogging treatments were initiated for both 2012 and 2013. Error bars represent \pm one standard deviation across subsamples that were replicated three times

Table 2. Average daily soil redox potential during the three day waterlogging duration in 2012 and 2013. The first sampling period occurred right after water was ponded on the soil surface. Error bars represent \pm one standard deviation across subsamples that were replicated three times

\begin{tabular}{|c|c|c|}
\hline \multirow{2}{*}{ Days of waterlogging } & \multicolumn{2}{|c|}{ Soil redox potential } \\
\hline & 2012 & 2013 \\
\hline & \multicolumn{2}{|c|}{ 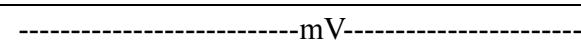 } \\
\hline 0 & $634 \pm 128$ & $455 \pm 18$ \\
\hline 1 & $494 \pm 42$ & $493 \pm 29$ \\
\hline 2 & $432 \pm 49$ & $454 \pm 23$ \\
\hline 3 & $448 \pm 72$ & $368 \pm 59$ \\
\hline
\end{tabular}

\subsection{Soil Ammonium and Nitrate}

In 2012, greater soil $\mathrm{NO}_{3}^{-}-\mathrm{N}$ concentrations of $45.4(\mathrm{P}=0.0053)$ and $49.5(\mathrm{P}=0.0024) \mathrm{mg} \mathrm{kg}^{-1}$ soil were observed with pre-plant $\mathrm{N}$ fertilizer treatments of NCU+NI and PCU in comparison to that of NCU in the waterlogging plots prior to waterlogging (Figure 3A). At the first soil sampling after waterlogging, there were $26.4(\mathrm{P}=0.0888)$ and $34.3(\mathrm{P}=0.0338)$ greater $\mathrm{mg} \mathrm{NO}_{3}{ }^{-}-\mathrm{N} \mathrm{kg}^{-1}$ soil ${ }^{-1}$ with $\mathrm{NCU}+\mathrm{NI}$ and $\mathrm{PCU}$ compared to $\mathrm{NCU}$, respectively. After three days of waterlogging, no differences were observed in soil surface $\mathrm{NO}_{3}{ }^{-} \mathrm{N}$ concentrations among pre-plant $\mathrm{N}$ fertilizers that were waterlogged, but PCU in the non-waterlogged treatment was $46.6(\mathrm{P}=0.0074)$ and $35.5(\mathrm{P}=0.0012) \mathrm{mg} \mathrm{NO}_{3}{ }^{-} \mathrm{N} \mathrm{kg}^{-1}$ soil greater than $\mathrm{NCU}$ and NCU+NI, respectively (Figures $3 \mathrm{~A}$ and $3 \mathrm{~B}$ ). Two days after draining the waterlogging treatment, the soil surface $\mathrm{NO}_{3}{ }^{-}-\mathrm{N}$ concentration was $71.0 \mathrm{mg} \mathrm{kg}^{-1}$ soil $(\mathrm{P}<0.0001)$ or $86 \%$ greater in the non-waterlogged control compared to the waterlogged treatment when averaged across pre-plant $\mathrm{N}$ fertilizer treatments (Figures $3 \mathrm{~A}$ and $3 \mathrm{~B}$ ). Similarly, soil $\mathrm{NH}_{4}{ }^{+}-\mathrm{N}$ concentrations prior to waterlogging were significantly higher with the PCU treatment compared to that of the control and other $\mathrm{N}$ fertilizer treatments (Figure 3C). After approximately two days of waterlogging, no differences in soil $\mathrm{NH}_{4}{ }^{+}-\mathrm{N}$ were observed among the $\mathrm{N}$ treatments (Figure 3C). In comparison, soil $\mathrm{NH}_{4}{ }^{+}-\mathrm{N}$ in the non-waterlogged control was generally higher with the PCU treatment compared to that of the control and 
other $\mathrm{N}$ fertilizer treatments but the concentrations were generally more variable over the sampling period (Figure 3D). The lack of difference in soil $\mathrm{NH}_{4}{ }^{+}-\mathrm{N}$ concentration between NCU and NCU+NI over the gas sampling period during and shortly after flooding suggest nitrapyrin activity was no longer effective at significantly reducing nitrification rates 59 days after $\mathrm{N}$ fertilization under the environmental conditions of this research. However, greater concentrations of soil $\mathrm{NO}_{3}{ }^{-} \mathrm{N}$ with $\mathrm{NCU}+\mathrm{NI}$ than $\mathrm{NCU}$ before and at soil waterlogging (Figure 3A) suggest nitrapyrin was effective at delaying nitrification and $\mathrm{NO}_{3}{ }^{-}-\mathrm{N}$ loss early after $\mathrm{N}$ fertilization. Omonode and Vyn (2013) reported an increased half-life of nitrapyrin when band-applied with UAN from 15 to 25 days in comparison to band applied UAN without nitrapyrin.

In 2013, all the $\mathrm{N}$ fertilizer treatments had significantly higher soil surface $\mathrm{NO}_{3}{ }^{-}-\mathrm{N}$ compared to the control prior to waterlogging (Figure 4A). A rapid decrease in soil $\mathrm{NO}_{3}^{-}-\mathrm{N}$ occurred with each day of waterlogging across all $\mathrm{N}$ fertilizer treatments (Figure 4A). At the end of the waterlogging duration, there was $32.3 \mathrm{mg} \mathrm{NO}_{3}-\mathrm{N} \mathrm{kg}^{-1}(61 \%)$ $(\mathrm{P}=0.0040)$ greater concentration in the soil of the non-waterlogged control compared to the waterlogged treatment when averaged across pre-plant $\mathrm{N}$ fertilizer treatments (Figure 4A and 4B). After two and three days of soil drainage, there were greater $\mathrm{NO}_{3}^{-}-\mathrm{N}$ concentrations of $41.4(\mathrm{P}=0.0003)(79 \%)$ and $26.7(\mathrm{P}=0.0165)(64 \%)$ $\mathrm{mg} \mathrm{kg}^{-1}$ in the soil when comparing the non-waterlogged control to the waterlogged treatment averaged across all pre-plant $\mathrm{N}$ treatments (Figures $4 \mathrm{~A}$ and $4 \mathrm{~B}$ ). No consistently significantly higher soil $\mathrm{NO}_{3}{ }^{-}-\mathrm{N}$ concentrations were observed among the $\mathrm{N}$ fertilizer treatments in both the waterlogged and non-waterlogged treatments during the sampling period (Figures 4A and 4B). As with 2012, soil $\mathrm{NH}_{4}{ }^{-}-\mathrm{N}$ concentrations prior to waterlogging were significantly higher with the PCU treatment compared to that of the control and other N fertilizer treatments and were decreased by waterlogging duration (Figure 4C).

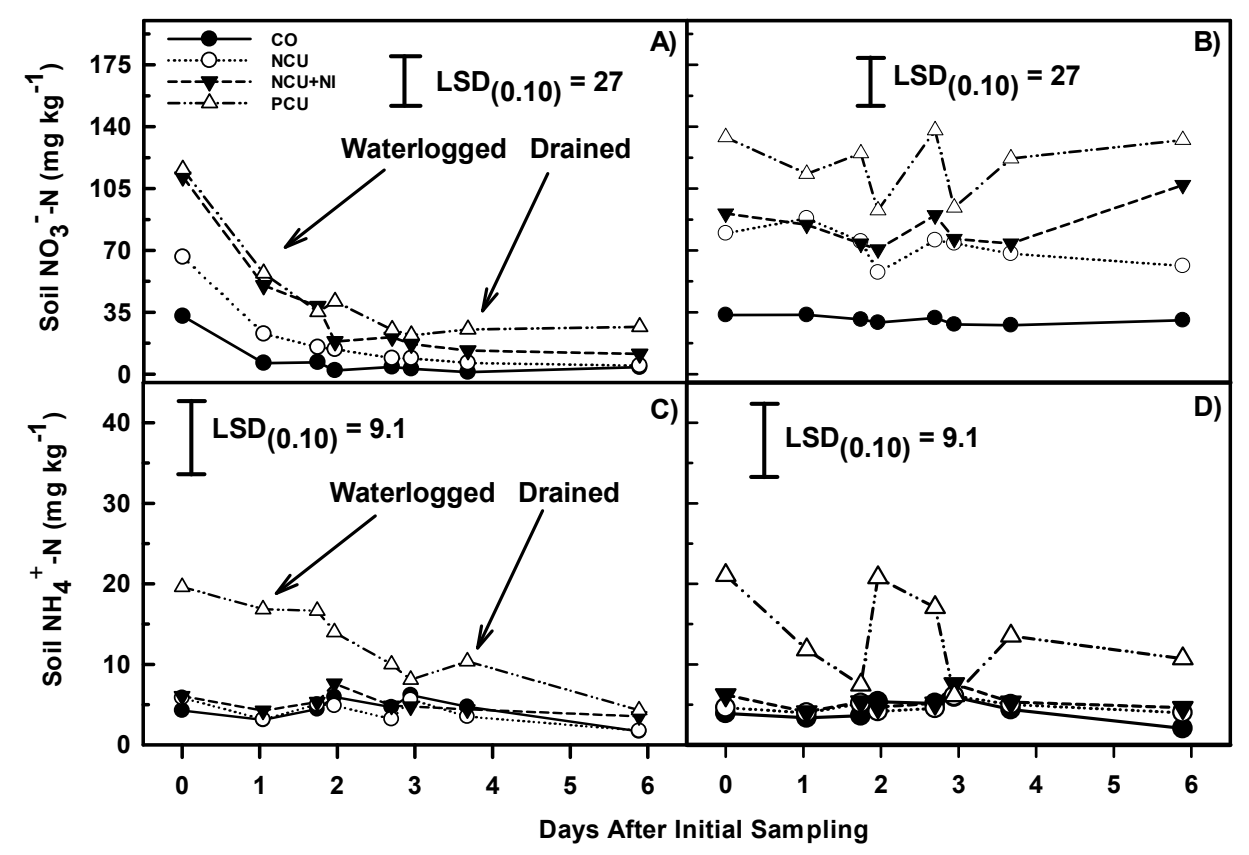

Figure 3. Soil $\mathrm{NO}_{3}^{-}-\mathrm{N}$ in the waterlogged (A) and non-waterlogged treatments (B) and soil $\mathrm{NH}_{4}{ }^{+}-\mathrm{N}$ in the waterlogged (C) and non-waterlogged treatments (D) measured at the time of gas sampling to a depth of $10 \mathrm{~cm}$ for each pre-plant $\mathrm{N}$ fertilizer treatment in 2012. (Abbreviations: CO, Control; NCU, Urea; NCU + NI, Urea + nitrification inhibitor; PCU, polymer coated urea; LSD, least significant difference at $P<0.10$ comparing pre-plant $\mathrm{N}$ treatments at similar times in the waterlogged and non-waterlogged treatments) 


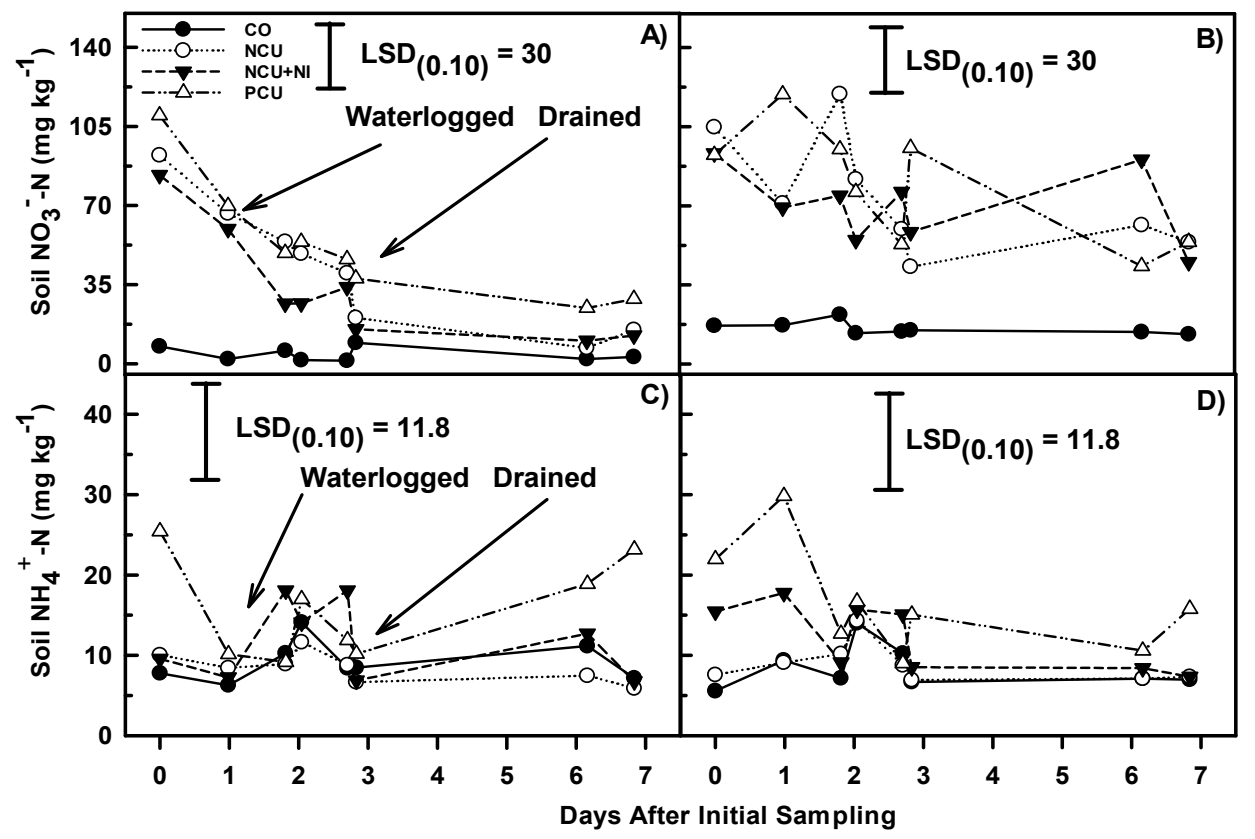

Figure 4. Soil $\mathrm{NO}_{3}{ }^{-} \mathrm{N}$ in the waterlogged (A) and non-waterlogged treatments (B) and soil $\mathrm{NH}_{4}{ }^{+}-\mathrm{N}$ in the waterlogged (C) and non-waterlogged treatments (D) measured at the time of gas sampling to a depth of $10 \mathrm{~cm}$ for each pre-plant $\mathrm{N}$ fertilizer treatment in 2013. (Abbreviations: CO, Control; NCU, Urea; NCU + NI, Urea + nitrification inhibitor; PCU, polymer coated urea; LSD, least significant difference at $P<0.10$ comparing pre-plant $\mathrm{N}$ treatments at similar times in the waterlogged and non-waterlogged treatments)

However, soil $\mathrm{NH}_{4}{ }^{+}-\mathrm{N}$ concentrations were significantly higher with PCU compared to that of the control and other $\mathrm{N}$ treatments four days after the waterlogged plots were drained (Figure 4C). In comparison, soil $\mathrm{NH}_{4}{ }^{+}-\mathrm{N}$ concentrations in the non-waterlogged treatment were only significantly higher with PCU compared to that of the control and the NCU treatment at the initiation and one day after initial sampling (Figure 4D).

Differential $\mathrm{N}$ loss with use of EEF versus conventional $\mathrm{N}$ fertilizer sources has been extensively reviewed (Motavalli et al., 2008) and is affected by several factors including the relative mode of action of the EEF, climate, soil drainage and $\mathrm{N}$ fertilizer management practices such as method and time of application. For example, $\mathrm{N}$ release from PCU is primarily affected by temperature and the moisture permeability of the polymer coating which would interact with soil moisture conditions (Trenkel, 1997). Therefore, at the V6 growth stage which occurred in early and mid-June during the two years of this research, differences in temperature and precipitation affected the relative amounts of soil $\mathrm{NH}_{4}{ }^{+}-\mathrm{N}$ and $\mathrm{NO}_{3}{ }^{-}-\mathrm{N}$ from the $\mathrm{N}$ fertilizer treatments prior to waterlogging. In poorly drained claypan soils in Missouri, major $\mathrm{N}$ losses during waterlogging have been primarily attributed to denitrification (Nash et al., 2012) and runoff (Udawatta et al., 2006). The results of this research indicate that significant soil surface $\mathrm{N}$ loss can occur within one day of soil waterlogging possibly due to gaseous losses.

\subsection{Soil $\mathrm{N}_{2} \mathrm{O}$ Emissions}

In 2012, no significant differences were observed in cumulative soil $\mathrm{N}_{2} \mathrm{O}-\mathrm{N}$ emissions among the $\mathrm{N}$ fertilizer treatments and the control in the non-waterlogged treatment during the sampling period (Figure 5A). In contrast, cumulative soil $\mathrm{N}_{2} \mathrm{O}-\mathrm{N}$ losses in the waterlogged treatment in 2012 did have significant differences and were $0.53,0.97,2.60$, and $3.74 \mathrm{~kg} \mathrm{ha}^{-1}$ for pre-plant $\mathrm{N}$ treatments of $\mathrm{CO}, \mathrm{NCU}, \mathrm{NCU}+\mathrm{NI}$, and PCU, respectively (Figure 5B). Polymer coated urea had $2.8 \mathrm{~kg} \mathrm{ha}^{-1}(\mathrm{P}=0.0288)$ greater cumulative soil $\mathrm{N}_{2} \mathrm{O}-\mathrm{N}$ emissions compared to that of NCU over the entire sampling period of the three day waterlogging treatment. This result may have been due to increased soil $\mathrm{NO}_{3}{ }^{-}-\mathrm{N}$ concentration of $25.1 \mathrm{mg} \mathrm{kg}^{-1}$ soil $(\mathrm{p}=0.0422)$ with PCU in comparison to that of NCU when averaged across all sampling times in 2012 (Figure 3A). Under rainfed conditions, Nash et al. (2012) observed similar cumulative emissions between NCU and PCU in two site years on a claypan soil later in the growing season. Under irrigated corn in a clay loam soil, Halvorson et al. (2013) reported no significant reduction of cumulative $\mathrm{N}_{2} \mathrm{O}$ emission with PCU under conventional tillage. These results 
indicated that yearly climate and timing of soil saturation may be significant factors in the amounts of soil $\mathrm{N}_{2} \mathrm{O}$ emissions relative to $\mathrm{N}$ fertilization and planting date. In addition, greater gaseous $\mathrm{N}$ loss as $\mathrm{N}_{2} \mathrm{O}$ or $\mathrm{NH}_{3}$ with NCU may have occurred prior to the sampling in this experiment.

Cumulative soil $\mathrm{N}_{2} \mathrm{O}-\mathrm{N}$ emissions during the 3-d waterlogging were not significantly different among the pre-plant $\mathrm{N}$ treatments (Table 3). However, increased emissions of $1.2(\mathrm{p}=0.0830)$ and $1.9(\mathrm{P}=0.0064) \mathrm{kg}$ $\mathrm{N}_{2} \mathrm{O}-\mathrm{N} \mathrm{ha}^{-1}$ resulted from NCU+NI and PCU in comparison to NCU during the soil drying phase of sampling, respectively (Table 3). This result may indicate that the increased cumulative $\mathrm{N}_{2} \mathrm{O}$ emission for PCU and $\mathrm{NCU}+\mathrm{NI}$ that occurred over the entire gas sampling time was more significantly impacted by $\mathrm{N}_{2} \mathrm{O}$ emissions during the soil drying down period than the waterlogging period. However, NCU had less cumulative emission during the drying down period than during the waterlogging period.

Increased soil $\mathrm{N}_{2} \mathrm{O}$ emissions during the soil drying period may have been attributed to $\mathrm{O}_{2}$ re-introduction into the soil pores as gravimetric water content decreased by $20.5 \%$. This re-introduction of $\mathrm{O}_{2}$ allows for $\mathrm{NH}_{4}$ oxidation to occur, providing substrates for $\mathrm{N}_{2} \mathrm{O}$ emission that were depleted during waterlogging. Several studies have observed peak soil $\mathrm{N}_{2} \mathrm{O}$ emissions when WFPS is at a range of 75 to $80 \%$ (Hansen et al., 1993; Khalil \& Baggs, 2005; Sey et al., 2008). Peng et al. (2011) observed $79 \%$ of the cumulative soil $\mathrm{N}_{2} \mathrm{O}$ emission occurred during the drying phase in rice production. Subtracting cumulative soil $\mathrm{N}_{2} \mathrm{O}$ of the non-fertilized control from the pre-plant $\mathrm{N}$ treatments in 2012 showed an average of $0.04 \%$ and $1.1 \%$ of total fertilizer $\mathrm{N}$ applied lost as $\mathrm{N}_{2} \mathrm{O}-\mathrm{N}$ in the non-waterlogged control and waterlogged treatments, respectively.

In 2013, there were no significant differences in cumulative $\mathrm{N}_{2} \mathrm{O}$ emissions of $\mathrm{CO}, \mathrm{NCU}, \mathrm{NCU}+\mathrm{NI}$, and PCU pre-plant $\mathrm{N}$ treatments in the non-waterlogged control when estimated over the entire sampling period (Figure $6 \mathrm{~A}$ ). In the waterlogged treatment, differences in cumulative soil $\mathrm{N}_{2} \mathrm{O}$ emissions due to $\mathrm{N}$ fertilizer source in 2013 for the entire gas sampling period were also not significant with $0.21,5.58,3.58$, and $4.80 \mathrm{~kg} \mathrm{~N}_{2} \mathrm{O}-\mathrm{N}$ ha ${ }^{-1}$ being emitted in the $\mathrm{CO}, \mathrm{NCU}, \mathrm{NCU}+\mathrm{NI}$, and $\mathrm{PCU}$ that received three days of waterlogging, respectively (Figure 6B). When pre-plant $\mathrm{N}$ treatments were analyzed during only the period of soil waterlogging, NCU-fertilized soil had $0.89 \mathrm{~kg} \mathrm{~N}_{2} \mathrm{O}-\mathrm{N}(\mathrm{P}=0.0731)$ greater emissions than PCU (Table 3). Other research examining use of EEF and subsurface drainage conducted over this approximate time period in a nearby location reported cumulative soil $\mathrm{N}_{2} \mathrm{O}$ emissions from PCU over the entire growing season to be $2 \%$ of applied $\mathrm{N}$, and that of NCU was $4 \%$ of applied N (Nash et al., 2015). Furthermore, Halvorson \& Del Grosso (2012) reported less cumulative emissions of $\mathrm{N}_{2} \mathrm{O}-\mathrm{N}(0.4 \%$ of applied $\mathrm{N})$ with $\mathrm{PCU}$ in comparison to NCU in an irrigated clay loam soil under no-till. When separated by a period of soil drying, NCU+NI had $0.83(\mathrm{P}=0.0946)$ and $0.87(\mathrm{P}=$ 0.0806) $\mathrm{kg} \mathrm{N}_{2} \mathrm{O}$ ha ${ }^{-1}$ less cumulative soil $\mathrm{N}_{2} \mathrm{O}$ emissions than NCU and PCU, respectively. Burzaco et al. (2013) reported a decrease of $0.60 \mathrm{~kg} \mathrm{ha}^{-1}$ of cumulative soil $\mathrm{N}_{2} \mathrm{O}-\mathrm{N}$ (24\% reduction) with the application of UAN plus nitrapyrin compared to applications of UAN alone when averaged across two research years. 


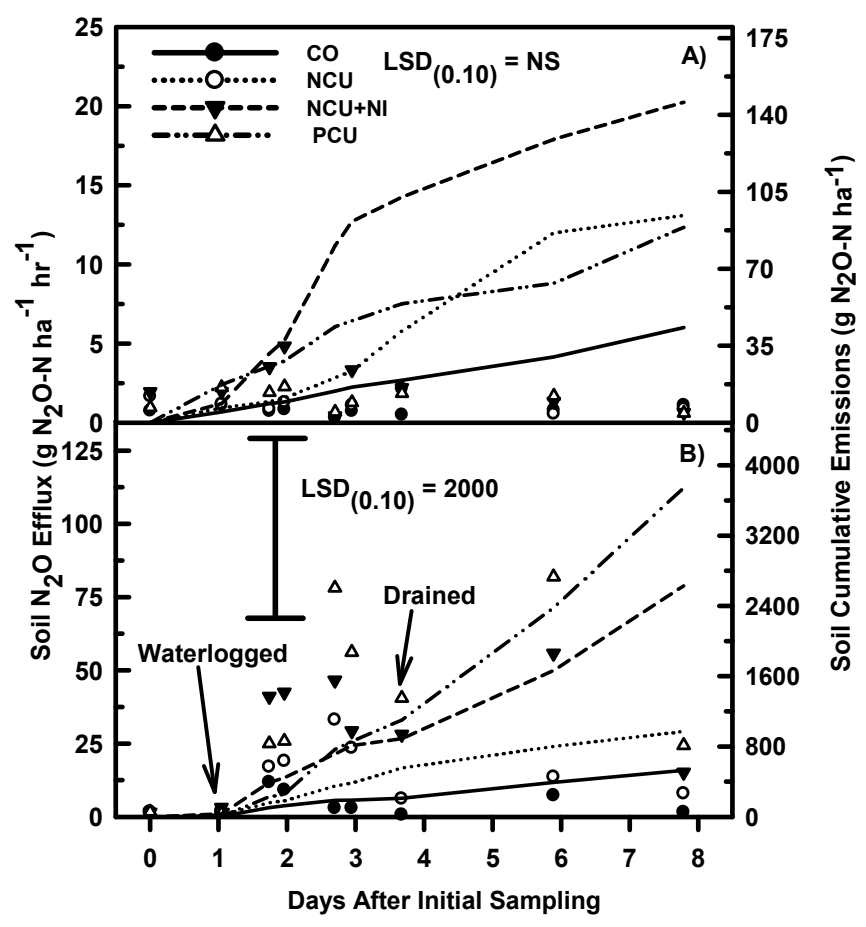

Figure 5. Soil $\mathrm{N}_{2} \mathrm{O}$ gas efflux and cumulative $\mathrm{N}_{2} \mathrm{O}$ emissions for each pre-plant $\mathrm{N}$ treatment in the non-waterlogged (A) and waterlogged treatment (B) in 2012 (Abbreviations: CO, Control; NCU, Urea; NCU +

NI, Urea + nitrification inhibitor; PCU, polymer coated urea; LSD, least significant difference at $P<0.10$ comparing cumulative gas emissions among pre-plant $\mathrm{N}$ treatments; NS, not significant)

Table 3. Cumulative $\mathrm{N}_{2} \mathrm{O}$ emissions for each pre-plant $\mathrm{N}$ treatment with three days of waterlogging and period of draining in 2012 and 2013

\begin{tabular}{|c|c|c|c|c|}
\hline \multicolumn{5}{|c|}{ Cumulative soil $\mathrm{N}_{2} \mathrm{O}-\mathrm{N}$ emissions } \\
\hline \multirow{2}{*}{ Pre-plant fertilizer } & \multicolumn{2}{|c|}{2012} & \multicolumn{2}{|c|}{2013} \\
\hline & Waterlogging period & Draining period & Waterlogging period & Draining period \\
\hline & & & \multicolumn{2}{|c|}{ 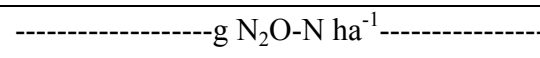 } \\
\hline $\mathrm{CO}$ & 206 & 262 & 46 & 79 \\
\hline NCU & 544 & 341 & 1922 & 1622 \\
\hline $\mathrm{NCU}+\mathrm{NI}$ & 886 & 1495 & 1628 & 791 \\
\hline PCU & 1134 & 2222 & 1028 & 1662 \\
\hline
\end{tabular}

Note. $\dagger$ (Abbreviations: CO, Control; NCU, Urea; NCU + NI, Urea + nitrification inhibitor; PCU, polymer coated urea; LSD, least significant difference at $P<0.10$ comparing cumulative gas emissions from 3 days of waterlogging and draining period for each pre-plant $\mathrm{N}$ treatment). 


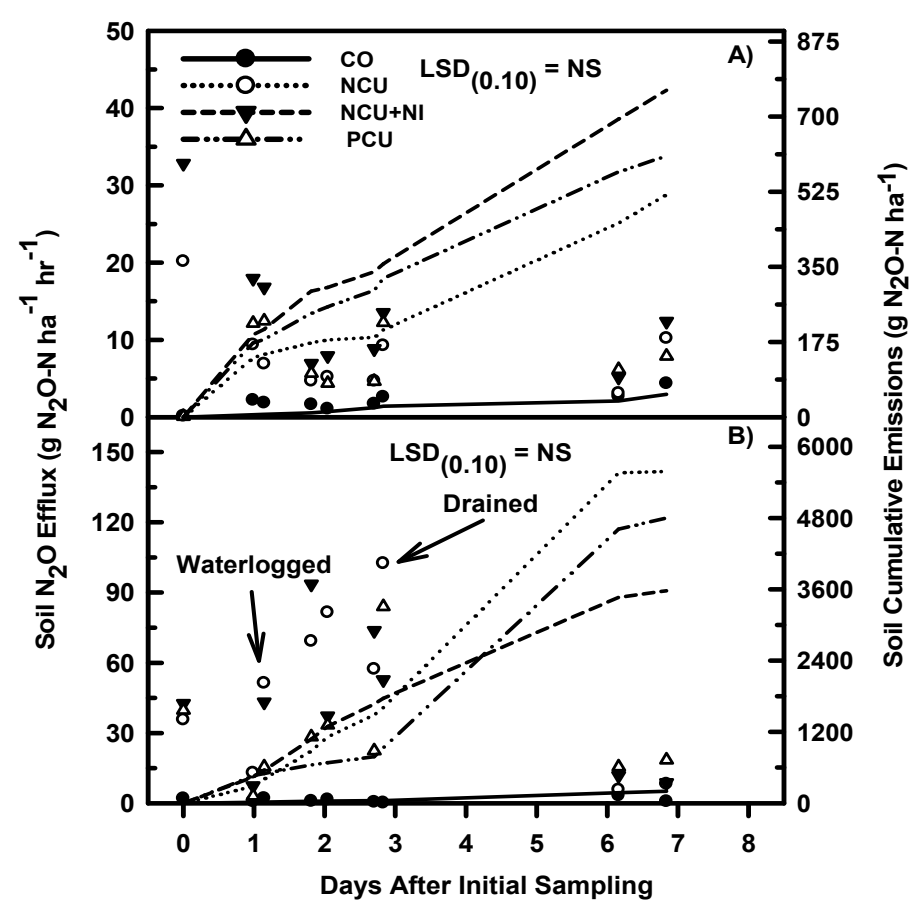

Figure 6. Soil $\mathrm{N}_{2} \mathrm{O}$ gas efflux and cumulative $\mathrm{N}_{2} \mathrm{O}$ emissions for each pre-plant $\mathrm{N}$ treatment in the non-waterlogged (A) and waterlogged treatment (B) in 2013 (Abbreviations: CO, Control; NCU, Urea; NCU +

NI, Urea + nitrification inhibitor; PCU, polymer coated urea; LSD, least significant difference at $P<0.10$ comparing cumulative gas emissions among pre-plant $\mathrm{N}$ treatments)

Subtracting cumulative soil $\mathrm{N}_{2} \mathrm{O}$ of the non-fertilized control from the pre-plant $\mathrm{N}$ treatments showed an average of $0.03 \%$ and $2.6 \%$ of total $\mathrm{N}$ applied loss as $\mathrm{N}_{2} \mathrm{O}-\mathrm{N}$ in 2013 in the non-waterlogged control and waterlogged treatments over the entire sampling period, respectively. Nash et al. (2012) reported a range of 2.8 to $3.0 \%$ of N fertilizer loss as $\mathrm{N}_{2} \mathrm{O}-\mathrm{N}$ with $\mathrm{NCU}$ and PCU in claypan soils, respectively over an entire growing season. Warmer temperatures in 2013 compared to that of 2012 and the difference in timing between the date of $\mathrm{N}$ fertilizer application and the date of the waterlogging between the two years may have impacted the higher cumulative soil $\mathrm{N}_{2} \mathrm{O}$ emissions observed in 2013 in the non-waterlogged and waterlogged treatment. The pulses of soil $\mathrm{N}_{2} \mathrm{O}$ emitted in this research that were associated with soil waterlogging and drying are in accordance with a review by Venterea et al. (2012) that stated that short-term pulses of soil $\mathrm{N}_{2} \mathrm{O}$ emissions in response to management practices and climatic events commonly account for a large proportion of annual emissions ( $>65 \%)$ in fertilized cropping systems.

\section{Conclusions}

During both years of this research, significant increases in cumulative soil $\mathrm{N}_{2} \mathrm{O}-\mathrm{N}$ emissions were observed under short-term waterlogging and dry down conditions compared to the non-waterlogged treatment. The effectiveness of the EEF products in reducing soil $\mathrm{N}_{2} \mathrm{O}-\mathrm{N}$ emissions were variable between the two years and may have been influenced by the differences in climate and the period of time between $\mathrm{N}$ fertilizer application and the waterlogging event that occurred each year. Given the relatively high proportion of soil $\mathrm{N}_{2} \mathrm{O}-\mathrm{N}$ emissions that can be associated with relatively short-term waterlogging events during corn production, further evaluation of the conditions that influence the effectiveness of EEF products or other management practices (e.g., drainage) may be warranted. In addition, management practices that effectively reduce the severity and duration of waterlogging and subsequent dry-down events may also assist in reducing cumulative soil $\mathrm{N}_{2} \mathrm{O}-\mathrm{N}$ emissions in poorly-drained fertilized soils. The prediction of the increased occurrence of extreme weather events in the Midwest region, including more frequent intense rainfall events during the spring, highlights the urgency of conducting this type of research.

\section{References}

Abendroth, L. J., Elmore, R. W., Boyer, M. J., \& Marlay, S. K. (2011). Corn growth and development. Iowa State Univ. Extension Publication \#PMR-1009. Retrieved May 8, 2014, from 
https://store.extension.iastate.edu/Product/Corn-Growth-and-Development

Akiyama, H., Yan, X., \& Yagi, K. (2010). Evaluation of effectiveness of enhanced efficiency fertilizers as mitigation options for $\mathrm{N}_{2} \mathrm{O}$ and $\mathrm{NO}$ emissions from agricultural soils: Meta-analysis. Global Change Biol., 16, 1837-1846. http://dx.doi.org/10.1111/j.1365-2486.2009.02031.x

Anderson, S. H., Gantzer, C. J., \& Brown, J. R. (1990). Soil physical properties after 100 years of continuous cultivation. J. Soil Water Conserv., 45, 117-121.

Association of American Plant Food Control Officials (AAPFCO). (2013). AAPFCO Official Publication, 65. Little Rock, AR: Association of American Plant Food Control Officials.

Bakken, L., \& Dörsch, P. (2007). Nitrous oxide emission and global changes: Modelling approaches. In H. Bothe, S. J. Ferguson, \& W. E. Newton (Eds.), Biology of the nitrogen cycle (pp. 381-396). Amsterdam, Netherlands: Elsevier. http://dx.doi.org/10.1016/B978-044452857-5.50026-6

Berner, R. A. (1981). A new geochemical classification of sedimentary environments. J. Sediment. Petrol., 51, 359-365.

Blake, G. R., \& Hare, K. H. (1986). Bulk density. In A. Klute (Ed.), Methods of soil analysis: Part 1-Physical and mineralogical methods (pp. 363-375). Madison, WI: Soil Science Society of America.

Bouwman, A. F., Boumans, L. J. M., \& Batjes, N. H. (2002). Emissions of $\mathrm{N}_{2} \mathrm{O}$ and NO from fertilized fields: Summary of available measurement data. Global Biogeochemical Cycles, 16, 1-13. http://dx.doi.org/10.1029/2001GB001811

Bronson, K. F., Mosier, A. R., \& Bishnoi, S. R. (1992). Nitrous oxide emissions in irrigated corn as affected by $\begin{array}{lllllll}\text { nitrification Soil. Soc. } & \text { Sibhibitors. }\end{array}$ http://dx.doi.org/10.2136/sssaj1992.03615995005600010025x

Buchholz, D. D. (2004). Soil test interpretations and recommendations handbook. Columbia, MO: Division of Plant Sciences, University of Missouri.

Burzaco, J. P., Smith, D. R., \& Vyn, T. J. (2013). Nitrous oxide emissions in Midwest US maize production vary widely with band-injected $\mathrm{N}$ fertilizers rates, timing and nitrapyrin presence. Environ. Res. Lett., 8, 1-11. http://dx.doi.org/10.1088/1748-9326/8/3/035031

Chintala, R., Owen, R. K., Schumacher, T. E., Spokas, K. A., McDonald, L. M., Malo, D. D., \& Bleakley, B. (2014). Denitrification kinetics in biomass and biochar amended soils of different landscape positions. Environmental Science and Pollution Research, 22(7), 5152-5163. http://dx.doi.org/10.1007/s11356-014-3762-2

Food and Agriculture Organization (FAO). (2009). FAO agricultural database. Rome, Italy: Food and Agriculture Organization.

Halvorson, A. D., \& Del Grosso, S. J. (2012). Nitrogen source and placement effects on soil nitrous oxide emissions from no-till corn. J. Environ. Qual., 41, 1349-1360. http://dx.doi.org/10.2134/jeq2012.0129

Halvorson, A. D., Snyder, C. S., Blaylock, A. D., \& Del Grosso, S. J. (2013). Enhanced-efficiency nitrogen fertilizers: Potential role in nitrous oxide emission mitigation. Agron. J., 105, 1-8.

Hansen, S., Maehlum, J. E., \& Bakken, L. R. (1993). $\mathrm{N}_{2} \mathrm{O}$ and $\mathrm{CH}_{4}$ fluxes in soil influenced by fertilization and tractor traffic. Soil Biol. Biochem., 25, 621-630. http://dx.doi.org/10.1016/0038-0717(93)90202-M

Hernandez-Ramirez, G., Brouder, S. M., Smith, D. R., Van Scoyoc, G. E., \& Michalski, G. (2009). Nitrous oxide production in an eastern corn belt soil: sources and redox range. Soil. Sci. Soc. Am. J., 73, 1182-1191. http://dx.doi.org/10.2136/sssaj2008.0183

Ji, Y., Liu, G., Ma, J., Zhang, G., Xu, H., \& Yagi, K. (2013). Effect of controlled-release fertilizer on mitigation of $\mathrm{N}_{2} \mathrm{O}$ emission from paddy field in South China: a multi-year field observation. Plant Soil, 371, 473-486. http://dx.doi.org/10.1007/s11104-013-1700-6

Khalil, M. I., \& Bags, E. M. (2005). $\mathrm{CH}_{4}$ oxidation and $\mathrm{N}_{2} \mathrm{O}$ emissions at varied soil water-filled pore spaces and headspace $\quad \mathrm{CH}_{4} \quad$ concentrations. Soil Biol. Biochem., $37, \quad$ 1785-1794. http://dx.doi.org/10.1016/j.soilbio.2005.02.012

Millar, N., Robertson, J. P., Grace, P. R., Gehl, R. J., \& Hoben, J. P. (2010). Nitrogen fertilizer management for nitrous oxide $\left(\mathrm{N}_{2} \mathrm{O}\right)$ mitigation in intensive corn (maize) production: an emissions reduction protocol for US Midwest agriculture. Mitig. Adapt. Strateg. Glob. Change, 15, 185-204. 
http://dx.doi.org/10.1007/s11027-010-9212-7

Motavalli, P. P., Goyne, K. W., \& Udawatta, R. P. (2008). Environmental impacts of enhanced efficiency nitrogen fertilizers. Crop Management. http://dx.doi.org/10.1094/CM-2008- 0730-02-RV.

Nash, P. R., Motavalli, P. P., \& Nelson, K. A. (2012). Nitrous oxide emissions from claypan soils due to nitrogen fertilizer source and tillage/fertilizer placement practices. Soil Sci. Soc. Am. J., 76, 983-993. http://dx.doi.org/10.2136/sssaj2011.0296

Nash, P., Motavalli, P., Nelson, K., \& Kremer, R. (2015). Ammonia and nitrous oxide gas loss with subsurface drainage and polymer-coated urea fertilizer in a poorly-drained soil. J. Soil and Water Conservation, 70, 267-275. http://dx.doi.org/10.2489/jswc.70.4.267

Nathan, M., Stecker, J., \& Sun, Y. (2006). Soil testing in Missouri: A guide for conducting soil tests in Missouri. Columbia, MO: Univ. of Missouri. Retrieved September 26, 2013, from http://soilplantlab.missouri.edu/soil/ec923.pdf

National Oceanic Atmospheric Administration (NOAA). (2012 and 2013). National Climatic Data Center. Retrieved April 1, 2014, from http://www.ncdc.noaa.gov/climate-monitoring

Omonode, R. A., \& Vyn, T. J. (2013). Nitrification kinetics and nitrous oxide emissions when nitrapyrin is coapplied with urea-ammonium nitrate. Agron. J., 105, 1475-1486. http://dx.doi.org/10.2134/agronj2013.0184

Parkin, T. B., \& Venterea, R. T. (2010). Chamber-based trace gas flux measurements. In R. F. Follett (Ed.), Sampling protocols (pp. 3-1 to 3-39). Available at: www.ars.usda.gov/research/GRACEnet.

Patricola, C. M., \& Cook, K. H. (2012). Mid-twenty-first century warm season climate change in the central United States. Part I: regional and global model predictions. Climate Dynamics, 40, 551-568. http://dx.doi.org/10.1007/s00382-012-1605-8

Peng, S., Hou, H., Xu, J., Mao, Z., Abudo, S., \& Luo, Y. (2011). Nitrous oxide emissions from paddy fields under different water managements in southwest China. Paddy Water Environ., 9, 403-411. http://dx.doi.org/10.1007/s10333-011-0275-1

Prinn, R., Cunnold, D., Rasmussen, R., Simmonds, P., Alyea, F., Crawford, A., \& Rosen, R. (1990). Atmospheric emissions and tends of nitrous oxide deduced from 10 years of ALE-GAGE data. Journal of Geophysical Research: Atmospheres, 95, 18369-18385. http://dx.doi.org/10.1029/JD095iD11p18369

Reddy, K. R., D’Angelo, E. M., \& Harris, W. D. (2000). Biogeochemistry of wetlands. In M. E. Summer (Ed.), Handbook of Soil Science (pp. G89-G119). Boca Raton, FL: CRC Press.

SAS Institute. (2013). SAS 9.3. Cary, NC: SAS Institute.

Sey, B., Manceur, A., Whalen, J., Gregorich, E., \& Rochette, P. (2008). Small scale heterogeneity in carbon dioxide, nitrous oxide and methane production from aggregates of a cultivated sandy-loam soil. Soil Biol. Biochem., 40, 2468-2473. http://dx.doi.org/10.1016/j.soilbio.2008.05.012

Solomon, S., et al. (2007). Technical Summary, Climate Change 2007: The Physical Science Basis. In S. Solomon, D. Qin, M. Manning, M. Marquis, K. B. Averyt, M. Tignor, \& Z. Chen (Eds.), Contribution of Working Group 1 to the Fourth Assessment Report of the Intergovernmental Panel on Climate Change (pp. 19-91). Cambridge, UK and NY, USA: Cambridge University Press.

Sposito, G. (1989). The chemistry of soils. New York, NY: Oxford University Press.

Tilman, D., Cassman, K. G., Matson, P. A., Nayler, R., \& Polasky, S. (2002). Agricultural sustainability and intensive production practices. Nature, 418, 671-677. http://dx.doi.org/10.1038/nature01014

Trenkel, M. E. (1997). Improving fertilizer use efficiency: Controlled-release and stabilized fertilizers in agriculture. Paris, France: International Fertilizer Industry Association.

Udawatta, R. P., Motavalli, P. P., Garrett, H. E., \& Krstansky, J. J. (2006). Nitrogen losses in runoff from three adjacent agricultural watersheds with claypan soils. Ag. Ecosys. Env., 117, 39-48. http://dx.doi.org/10.1016/j.agee.2006.03.002

University of Missouri Extension. (2014). Missouri historical agricultural weather database: Novelty (Knox County). Columbia, MO: University of Missouri Extension. Retrieved from http://agebb.missouri.edu/weather/history/index.asp?station_prefix=nov

USEPA. (2009). Inventory of U.S. Greenhouse Gas Emissions and Sinks: 1990-2007. Washington, DC: U.S. 
Environmental Protection Agency (USEPA). Retrieved March 23, 2009, from http://epa.gov/climatechange/emissions/usinventoryreport.html

Venterea, R. T., Halvorson, A. D., Kitchen, N. R., Liebig, M. A., Cavigelli, M. A., Del Grosso, S. J., \& Collins, H. P. (2012). Challenges and opportunities for mitigating nitrous oxide emissions from fertilized cropping systems. Frontiers in Ecology and the Environment, 10, 562-570. http://dx.doi.org/10.1890/120062

Vepraskas, J. L. (2002). Redox potential measurement (pp. 1-17). Chapel Hill, NC: University of North Carolina Soil Science Department.

Villarini, G., Smith, J., \& Vecchi, G. A. (2013). Changing frequency of heavy rainfall over the Central United States. Journal of Climate, 26, 351-357. http://dx.doi.org/10.1175/JCLI-D-12-00043.1

Watson, F. C. (1979). Soil survey of Knox, Monroe, and Shelby counties, Missouri. Washington, DC: Soil Conservation Service, U.S. Dept. of Agric.

Wuebbles, D. J. (2009). Nitrous oxide: No laughing matter. Science, 326, 56-57. http://dx.doi.org/10.1126/science.1179571

Zhi-Guang, L. (1985). Oxidation-reduction potential. In Y. Tian-Ren (Ed.), Physical Chemistry of Paddy Soils (pp. 1-26). Berline, Germany: Springer Verlag.

Zhu, T., \& Sikora, F. J. (1995). Ammonium and nitrate removal in vegetative and unvegetative wetlands. Water Sci. Techn., 32, 219-228. http://dx.doi.org/10.1016/0273-1223(95)00623-0

Zhu, X., Burger, M., Doane, T. A., \& Horwath, W. R. (2013). Ammonia oxidation pathways and nitrifier denitrification are significant sources of $\mathrm{N}_{2} \mathrm{O}$ and $\mathrm{NO}$ under low oxygen availability. Proc. Natl. Acad. Sci., U.S.A., 110, 6328-6333. http://dx.doi.org/10.1073/pnas.1219993110

\section{Copyrights}

Copyright for this article is retained by the author(s), with first publication rights granted to the journal.

This is an open-access article distributed under the terms and conditions of the Creative Commons Attribution license (http://creativecommons.org/licenses/by/3.0/). 